EMPOWER: Jurnal Pengembangan Masyarakat Islam

Vol. 5, No. 2, Desember 2020, hlm. 74-91

e-ISSN: 2580-0973, p-ISSN: 2580-085X

Tersedia online di: http://syekhnurjati.ac.id/jurnal/index.php/empower

Email: empowerjurnal@gmail.com

\title{
Implementasi Program Filantropi oleh Yayasan Amanah Ummat Muslimin (YAUM) Cirebon
}

\author{
Istiqomah* \\ (Program Studi Pengembangan Masyarakat Islam, \\ Fakultas Ushuludin Adab dan Dakwah, IAIN Syekh Nurjati Cirebon) \\ E-mail : Istiqomah 0406@yahoo.co.id \\ Paras Suci Dara Wati** \\ (Mahasiswi Pengembangan Masyarakat Islam, \\ Fakultas Ushuludin Adab dan Dakwah, IAIN Syekh Nurjati Cirebon) \\ E-mail : paras.suci1999@gmail.com \\ Article History \\ Submitted: 03.11.2020, Revised: 30.11.2020, Accepted: 14.12 .2020
}

\begin{abstract}
Philanthropy is a good deed or charity setting aside a portion of one's assets in order to help the poor. This research will look at the implementation of the Philanthropy program carried out by YAUM Cirebon both during normal times and during this pandemic situation. This research uses descriptive qualitative methods with data collection techniques using interviews, observation and documentation study. Researchers found that the implementation of the philanthropic program carried out by YAUM Cirebon is divided into five major programs, namely humanitarian social donations, educational donations, public da'wah donations, donations for health and YAUM donations for the people. besides that, there are special programs carried out during the pandemic. Assistance in the form of basic necessities for poor people who need PPE, masks, hand sanitizer, and boots to several medical institutions in the Cirebon area.
\end{abstract}

Keywords: implementation, philanthropy, YAUM Cirebon 


\begin{abstract}
Abstrak
Filantropi adalah perbuatan baik atau beramal menyisihkan sebagian hartanya dalam rangka membantu masyarakat dhuafa. pada penelitian ini akan melihat implementasi program Filantropi yang dilakukan oleh YAUM Cirebon baik ketika masa normal maupun ketika situasi pandemi ini. penelitian ini menggunakan metode kualitatif deskriptif dengan teknik pengumpulan data menggunakan wawancara, observasi dan studi dokumentasi. Peneliti menemukan bahwa implementasi program filantropi yang dilakukan oleh YAUM Cirebon terbagi menjadi lima program besar yaitu donasi sosial kemanusiaan, donasi pendidikan, donasi dakwah keumatan, donasi untuk kesehatan dan donasi YAUM untuk umat. selain itu ada program khusus yang dilakukan ketika masa pandemi. Bantuan berupa sembako bagi masyarakat dhuafa yang membutuhkan dana bantuan APD, masker, hand sanitizer, dan sepatu boots kepada beberapa institusi medis di wilayah cirebon.
\end{abstract}

Kata kunci: impelementasi, filantropi, YAUM Cirebon

\title{
PENDAHULUAN
}

Potensi zakat di Indonesia mencapai 462 triliun rupiah setara dengan 3,4\% PDB Nasional. Bahkan jika pengumpulan zakat dikatgorikan sebagai instrument pengurangan pajak, maka total potensi zakat akan lebih besar ${ }^{1}$. Pertumbuhan pengumpulan ZIS tahun 2002-2017 dirata-rata mencapai 35,10\% dan dapat dipastikan akan semakin meningkat setiap tauhnnya2. Potensi yang besar ini harus dimanfaatkan secara optimal.

Organisasi pengelola zakat di Indonesia berdasarkan Undangundang nomer 23 Tahun 2011 tentang Pengelolaan Zakat dapat dikelompokan menjadi dua yaitu Badan Amil Zakat dan Lembaga Amil Zakat. Badan amil zakat yang berada di bawah naungan pemerintahan langsung dan lembaga amil zakat yang dibentuk oleh masyarakat. Tidak

\footnotetext{
${ }^{1}$ Harry Djatmiko, "Re-Formulation Zakat System as Tax Reduction in Indonesia," Indonesian Journal of Islam and Muslim Societies 9, no. 1 (24 Mei 2019): 135, https://doi.org/10.18326/ijims.v9i1.135-162.

2 BASZNAS, Statistik Zakat Nasional 2017, Badan Amil Zakat Nasional (Jakarta: Bagian Liaison dan Pelaporan, 2018), 16, file://C:/Users/User/Downloads/fvm939e.pdf. 
ada perbedaan mendasar antara kedua lembaga ini. Secara umum lembagalemabaga ini memiliki perhatian lebih dalam memanfaatkan potensi zakat yang ada di Indonesia. Terlepas dari catatan kritis terhadap munculnya undang-undang tersebut ${ }^{3}$, itikad baik pemerintah untuk mewujudkan kesejahteraan sosial melalui mobilisasi dana zakat perlu diapresiasi.

Dengan menerbitkan undang-undang pengelolaan zakat maka potensi yang ada akan dapat di petakan serta terakomodir dengan baik. Data menunjukan bahwa pada tahun 2017 Baznas mengumpulkan dana ZIS sebesar 153-an milyar, Baznas Provinsi sebesar 448-an milyar, Baznas Kabupaten/Kota sebesar 3,4-an triliyun dan LAZ sebesar 2,9-an triliyun 4 Tetap saja, angka tersebut baru sebesar $1 \%$ dari potensi yang ada di Indonesia 5 .

Setelah WHO resmi menetapkan virus corona atau COVID-19 sebagai pandemi pada 11 maret 2020, kemudian disusul oleh Indonesia melalui BNPB menetapkan sebagai Bencana Nasional Non-Alam pada tanggal 14 maret 20206. Maka, Akan ada peningkatan pengelolaan ZIS di Indonesia. Mengapa demikian? data menunjukan bahwa terdapat korelasi antara meningkatnya angka ZIS dengan bencana yang terjadi di Indonesia, pengumpulan ZIS meningkat hingga $76 \%$ pada saat gempa dan tsunami Aceh dan 96 \% pada saat gempa Yogyakarta7. Menarik dilihat adalah bagaimana pengelolaan ZIS ditengah situasi pandemi ini baik oleh badan amil zakat maupun lembaga amil zakat.

Pada tulisan ini, peneliti akan melihat peran salah satu lembaga amil zakat di Kabupaten Cirebon yaitu Yayasan Amanah Umat Muslimin(YAUM) Cirebon. Bagaimana implementasi program yang sudah

\footnotetext{
3 Saidurrahman, "The Politics of Zakat Management in Indonesia: The Tension between BAZ and LAZ," Journal of Indonesian Islam 7, no. 2 (1 Desember 2013): 379, https://doi.org/10.15642/JIIS.2013.7.2.366-382.

${ }^{4}$ BASZNAS, Statistik Zakat Nasional 2017, 4.

${ }^{5}$ BAZNAS, Indonesia Zakat Outlook 2019 (Jakarta: PUSKAS BAZNAS, 2019), 2-3.

${ }^{6}$ BNPB, "Status Keadaan Tertentu Darurat Bencana Wabah Penyakit Akibat Virus Corona di Indonesia," bnpb.go.id, 2020, https://bnpb.go.id/berita/status-keadaantertentu-darurat-bencana-wabah-penyakit-akibat-virus-corona-di-indonesia-.

7 BASZNAS, Statistik Zakat Nasional 2017, 16.
} 
dilakukan oleh lembaga tersebut baik dalam kondisi normal maupun saat pandemi ini?.

Untuk mendukung tulisan ini, peneliti mencari beberapa penelitian terdahulu agar dapat melihat letak perbedaan dan kebaharuan dari penelitian ini. terdapat tiga penelitian yang akan disampaikan pertama adalah penelitian yang sama menunjukan keresahaan akan besarnya potensi ZISWAF8 $^{8}$ yang belum dikelola dengan baik. penelitian ini mengarahkan untuk merubah sudut pandang pendistribusian ZISWAF dari yang sebelumnya karitatif dirubah menjadi pemberdayaan yang berkalnjutan. Bahkan terdapat beberapa lembaga pengelola ZISAF berhasil melakukannya. ${ }^{9}$ Penelitian kedua adalah penelitian mengenai Lembaga Sosial Pesantren Tebuireng ${ }^{10}$ dalam mensejahterakan masyarakat Jombang. Beberapa temuan lapangan menujukan bahwa implementasi program sudah cukup baik meskipuna da beberapa catatan dalam manajemen perencanaan pada program ekonomi. Terakhir adalah penelitian yang berkaitan dengan lembaga amil zakat yang dilakukan oleh Lembaga Amil Zakat Nahdlatul Ulama(LAZISNU) ${ }^{11}$ Kabupaten Cirebon. Hasil penelitian menunjukan bahwa pendistribusian sudah cukup baik tetapi manajemen

8 Deden Gandana Madjakusumah dan Udin Saripudin, "Pengelolaan Dana Lembaga Filantropi Islam Dalam Pengembangan Ekonomi Umat," SERAMBI: Jurnal Ekonomi Manajemen dan Bisnis Islam 2, no. 1 (30 April 2020): 41-50, https://doi.org/10.36407/serambi.v2i1.151.

9 Pajar Hatma Indra Jaya, “'Mas Zakky': Model Zakat pemberdayaan dari Baznas Kota Yogyakarta," Jurnal Pemberdayaan Masyarakat: Media Pemikiran dan Dakwah Pembangunan 2, no. 2 (23 Juni 2019): 227-52, https://doi.org/10.14421/jpm.2018.02202; Sriharini dan Moh Abu Suhud, "Warung Beres Sebagai Modal Sosial Meningkatkan Produktifitas Ekonomi Umat: Studi Pemberdayaan Komunitas oleh Lembaga Amil Zakat Dompet Dhuafa Jogja di Kabupaten Gunungkidul," Jurnal Pemberdayaan Masyarakat: Media Pemikiran dan Dakwah Pembangunan 1, no. 1 (10 Agustus 2017): 119, https://doi.org/10.14421/jpm.2017.011-06.

${ }^{10}$ Rochmatul Chuswinta, Tri Sudarwanto, dan M. Syam'un Rosyadi, “Implementasi Pengelolaan Dana Infaq Dalam Meningkatkan Kesejahteraan Masyarakat Jombang (Studi Kasus Lembaga Sosial Pesantren Tebuireng"LSPT")," JIES: Journal of Islamic Economics Studies, vol. 1, 4 November 2020, https://ejournal.feunhasy.ac.id/jies.

11 Ades Sugita, Dan Sri, dan Intan Wulandari, "Analisis Peranan Pengelolaan Dana Ziswaf Dalam Pemberdayaan Ekonomi Umat Pada Lazisnu Kabupaten Cirebon," Jurnal Indonesia Sosial Sains, vol. 1, 28 Juli 2020, https://doi.org/10.36418/JISS.V1I1.6. 
pengelolaannya perlu ada perbaikan pada beberapa hal. Beberpa penelitian tersbeut menunjukan bahwa ada kesamaan fokus pada penelitian ini, sejatinya penelitian ini bukanlah penelitian yang benar-benar baru. Tetapi ada perbedaan yang bisa digaris bawahi antara penelitian terdahulu dengan tulisan ini yaitu implementasi program-program pendistribusian ZIS yang dilakukan oleh lembaga amil zakat pada masa pandemi ini.

Penelitian ini menggunakan metode deskriptif kualitatif yang didalamnya berisikan data Data primer dan data sekunder ${ }^{12}$. Data primer ialah data yang diperoleh atau dikumpulkan langsung di lapangan oleh orang yang melakukan penelitian atau yang bersangkutan yang memerlukannya. Data primer ini di dapat dari sumber informan yaitu individu atau perseorangan seperti hasil wawancara yang dilakukan oleh peneliti. Peneliti melakukan wawancara kepada pengurus YAUM Cirebon. sedangkan data sekunde ialah data yang diperoleh atau dikumpulkan oleh orang yang melakukan penelitian dari sumber-sumber yang telah ada. Data ini dugunakan untuk mendukung informasi primer yang telah di peroleh yaitu dari buku, jurnal, skripsi, dan lain-lain. Data sekunder pada penelitian ini berupa data yang diperoleh dari media daring, data profil yayasan dan beberapa informasi di media sosial lembaga tersebut.

Teknik pengumpulan data merupakan langkah yang paling strategis dalam penelitian, karena tujuan utama dari penelitian adalah mendapatkan data. tanpa mengetahui teknik pengumpulan data, maka peneliti tidak akan mendapatkan data yang memenuhi standar data yang ditetapkan. Pada penelitian ini menggunakan Teknik pengumulan data yaitu pengamatan (observasi), wawancara, dan studi dokumentasi. Pertama, pengamatan (observasi) merupakan suatu proses yang kompleks, suatu proses yang tersusu dari berbagai proses biologis dan psikhologis. Dua di antara yang terpenting adalah proses-proses pengamatan dan ingatan. Dalam penelitian disini, penulis melakukan observasi partisipan. Peneliti ikut mengamati apa yang dikerjakan orang, mendengarkan apa yang mereka ucapkan, dan

${ }_{12}$ M. Iqbal Hasan, Pokok-pokok Metodologi Penelitian dan Apliaksinya (Bogor: Ghalia Indonesia, 2002). 
partisipasi dalam aktivitas mereka. ${ }^{13}$ Dalam penelitian disini, penulis ikut terlibat dalam kegiatan program-program YAUM Cirebon, salah satunya Jum'at Berkah yang dilakukan oleh YAUM Cirebon setiap hari Jumat.

Kedua, wawancara merupakan pertemuan dua orang untuk bertukar informasi dan ide melalui Tanya jawab, sehingga dapat di kontruksikan makna dalam suatu topik tertentu. ${ }^{14}$ Dalam penelitian disini, penulis melakukan wawancara kepada beberapa relawan YAUM Cirebon yang selama ini selalu ikut berkontribusi dalam kegiatan program YAUM salah satunya adalah kegiatan Jum'at Berkah. Informan tersebut adalah Ati Fatimah, Silvia dan Septiyani. Ketiga, dokumentasi adalah suatu cara yang digunakan untuk memperoleh data dan informasi dalam bentuk buku, arsip, dokumen, tulisan angka dan gambar yang berupa laporan serta keterangan yang dapat mendukung penelitian. Dalam penelitian disini, penulis melakukan pemotretan pada setiap proses kegiatan dan tempattempat yang ada kaitannya dengan fokus kajian penulis/peneliti.

\section{HASIL DAN PEMBAHASAN}

\section{Implementasi dan Perkembangan Filantropi Islam}

Implementasi mengacu pada tindakan untuk mencapai tujuantujuan yang telah diterapkan dalam suatu keputusan. Tindakan ini berusaha untuk mengubah keputusan-keputusan tersebut menjadi polapola operasional serta berusaha mencapai perubahan-perubahan besar atau kecil sebagaimana yang telah diputuskan sebelumnya.15 Maka dari itu, implementasi di sini adalah apa saja bentuk atau kegiatan yang dirancang dan dilakukan guna mencapai tujuan yang sudah ditetapkan sebelumnya. Dalam penelitian ini akan spesifik berbicara tentang kegiatan-kegiatan apa saja yang sudah dilakukan oleh YAUM Cirebon dalam mencapai sasaran dan tujuannya.

\footnotetext{
13 Sugiyono, Metode Penelitian Kuantitatif Kualitatif dan RED (Bandung: Alfabeta, 2010), 227.

14 Sugiyono, Metode Penelitian Kuantitatif Kualitatif dan RED.

15 Deddy Mulyadi, Studi Kebijakan Publik dan Pelayanan Publik (Bandung: Alfabeta, 2015), 12.
} 
Filantropi merupakan salah satu pendekatan dari tiga pendekatan untuk mempromosikan kesejahteraan sosial termasuk di dalamnya upaya pengentasan kemiskinan, yaitu pendekatan sosial service (pelayanan sosial), social work (pekerjaan sosial) dan philanthropy (Filantropi). ${ }^{16}$ Kata "Filantropi" berasal dari Bahasa Inggris Philantropy, dan kata tersebut berakar dari Bahasa Yunani, yaitu Philos (cinta) dan Anthropos (manusia). Dari akar kata ini, kita definisikan "filantopi" sebagai perbuatan berderma untuk sesama manusia. Sementara itu, Payton dan Moody mendefinisikan "filantropi" sebagai voluntary action for the public good (tindakan sukarela untuk kepentingan kemaslahatan publik). ${ }^{17}$

Filantopi dapat diartikan sebagai perilaku manusia untuk menolong sesama dalam bentuk kegiatan berderma, atau kebiasaan beramal dari seseorang yang dengan ikhlas menyisihkan sebagaian hartanya atau sumberdaya yang dimikinya untuk disumbangkan kepada orang yang membutuhkan. Filantropi dalam makna ini diwujudkan dalam perbuatan baik. ${ }^{18}$

Secara umum filantropi didefinisikan sebagai tindakan sukarela untuk kepentingan publik. menurut sifatnya, dikenal dua bentuk filantropi, yaitu filantropi tradisional dan filantropi modern. Filantropi tradisional adalah filantropi yang berbasis karitas(charity) atau belas kasihan yang pada umumnya berbentuk pemberian untuk kepentingan pelayanan sosial seperti pemberian para dermawan kepada kaum miskin untuk mebantu kebutuhan makanan, pakaian, tempat tinggal, dan lain-lain. Filantropi modern yang lazim disebut filantropi untuk pembangunan Sosial dan keadilan Sosial merupakan bentuk kedermawanan sosial yang dimaksudkan untuk menjembatani jurang antara si kaya dengan si miskin. Jembatan tersebut diwujudkan dalam upaya mobilisasi sumber daya untuk

\footnotetext{
${ }^{16}$ Imron Hadi Tamim, "Peran Filantropi dalam Pengentasan Kemiskinan di dalam Komunitas Lokal," The Sociology of Islam 1, no. 1 (2011): 36, http://jurnalfisip.uinsby.ac.id/index.php/JSI/article/view/8.

${ }_{17}$ Robert L. Payton dan Michael P. Moody, Understanding Philanthropy: Its Meaning and Mission (Indianapolis: Indiana University Press, 2008).

${ }_{18}$ M. Zaky Wahyuddin Azizi, “Optimalisasi Peran Lembaga Filantropi Islam,” vol. 01 (Surakarta, 2007), http://publikasiilmiah.ums.ac.id/handle/11617/1061.
} 
mendukung kegiatan yang menggugat ketidakadilan struktur yang menjadi penyebab kemiskinan dan ketidakadilan. ${ }^{19}$

Dapat disimpulkan bahwa filantropi (kedermawanan) adalah kesadaran untuk memberi dalam rangka mengatasi kesulitan dan meningkatkan kesejahteraan hidup masyarakat secara luas dalam berbagai bidang kehidupannya. Dalam pandangan ajaran Islam, filantropi adalah perbuatan yang sangat mulia, bagian utama dari ketakwaan seorang muslim, perbuatan yang akan mengundang keberkahan, rahmat dan pertolongan Allah, perbuatan yang akan menyelamatkan kehidupan secara luas. ${ }^{20}$

Potensi filantropi umat Islam terwujud dalam bentuk zakat, wakaf, hibah, dan derma-derma lainnya. Adapun pondasi filantropi islam dalam praktek dapat ditemukan dalam Al-Qur'an surat At-Taubah:60.

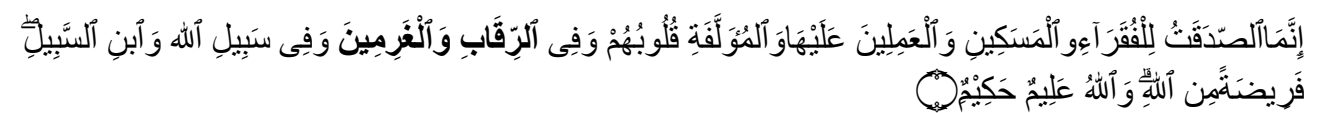

"Sesungguhnya zakat-zakat itu hanyalah untuk orang-orang fakir, orang-orang miskin, pengurus-pengurus zakat, para mu'alllaf yang dibujuk hatinya, untuk (memerdekakan) budak, untuk orang-orang yang berhutang, untuk keperluan jalan Allah, dan untuk mereka yang sedang dalam perjalanan, sebaga suatu ketetapan yang diwajibkan oleh Allah, dan Allah Maha mengetahui lagi maha Bijaksana."

Dalam perkembangan sejarah islam, kegiatan filantropi ini dikembangkan dengan berdirinya lembaga-lembaga yang mengelola sumber daya yang berasal dari kegiatan filantopi yang didasari anjuran bahkan perintah yang terdapat dalam Al-Qur'an dan Hadis. Selanjutnya lembaga filantopi ini semakin menunjukan signifikannya, di antarnya

\footnotetext{
${ }^{19}$ Chusnan Jusuf, "Filantropi Modern untuk Pembangunan Sosial," Sosio Konsepsia, vol. 12, 1 Januari 2007, https://doi.org/10.33007/SKA.V12I1.621.

20 Admin, "Filantropi dalam Perspektif Islam," republika.co.id, diakses 12 Desember 2020, https://republika.co.id/berita/p5qn6r396/filantopi-dalam-persfektifislam.
} 
karena perannya dalam upaya mengurangi kesenjangan sosial (ekonomi) dalam masyarakat. ${ }^{21}$

\section{Yayasan Amanah Ummat Muslimin (YAUM) Cirebon Sebagai Sebuah Lembaga Amil Zakat}

Yayasan Amanah Ummat Muslimin (YAUM) Cirebon berdiri pada tahun 2017, didirikan oleh dr. Wizhar dan kawan-kawan. YAUM Cirebon adalah lembaga (keumatan) yang berintegrasi dalam kegiatan yang berhubungan dengan zakart, infaq sodaqoh, dan waqaf. Tujuannya adalah menjadi salah satu lembaga sosial yang dapat berkhidmat dan berkontribusi kepada Ummat, bangsa dan Negara, terutama di wilayah Cirebon dan sekitarnya. Pelaksanaan program YAUM tidak terlepas dari peran dan partisipasi para donator. YAUM Cirebon berlokasi di kayuwalang, Kelurahan Karya Mulya, Kecamatan Kesambi, Kota Cirebon. Kantor YAUM Cirebon berada di tengah-tengah dekat dengan masyarakat tujuannya agar bisa bersinergi dengan masyarakat sekitar. ${ }^{22}$

YAUM Cirebon sempat vakum tidak lama setelah berdiri, sampai kurang lebih selama satu tahun. Hal tersebut dikarenakan manajemen YAUM tidak dikelola dengan professional dan komprehensif. Pengurus yang sudah punya kesibukan mata pencaharian dibidangnya masingmasing menjadikan YAUM sebagai aktivitas sampingan, hal tersebut menjadi penyebab utama. YAUM baru dapat dikelola secara profesional pada tahun 2018 tepatnya bulan April. Kesungguhan para pendiri juga disupport oleh donator menjadi komitmen utama untuk menjadikan YAUM sebagai lembaga sosial yang berkhidmat dengan memberikan manfaat maksimal kepada ummat. Sudah banyak program-program sosial dan dakwah keummatan telah dilaksankan. Program Donasi Sosial kemanusiaan, Donasi Pendidikan, Donasi dakwah keummatan, Donasi untuk kesehatan, Donasi YAUM untuk Ummat. ${ }^{23}$

\footnotetext{
21 Abdiansyah Linge, "Filantropi Islam Sebagai Instrumen Keadilan Ekonomi," JURNAL PERSPEKTIF EKONOMI DARUSSALAM 1, no. 2 (2 Maret 2017): 154-71, https://doi.org/10.24815/jped.v1i2.6551.

${ }_{22}$ Buku Profil Yayasan Amanah Umat Muslimin Cirebon

${ }^{23}$ Buku Profil Yayasan Amanah Umat Muslimin Cirebon
} 
Yayasan ini adalah yayasan yang bergerak dibidang sosial, keagamaan dan pendidikan. YAUM Cirebon sendiri memiliki hubungan yang cukup harmonis dengan Yayasan Kesejahteraan Madani(Yakesma). Lembaga ini memiliki visi "Menjadi Lembaga Sosial Terdepan" ditunjang dengan empat misi yaitu pertama memperkokoh karakter yang tangguh, dengan sumber daya yang berkualitas, eligius dan profesional. Kedua, memberikan pelayanan terbaik dan tersu diptamilkan. Ketiga, pengelola program secara profesional dan dapat dipertanggung jawabkan, kelima, membangun jejaring ukhuwah dengan elemen-elemn yang mempunyai semangat kebaikan dan solusi dalam rangka berkontribusi untuk umat.

Selain memiliki visi dan misi, sebuah lembaga juga perlu menentukan tujuan dan sasaran yang ingin di capaia. Setidaknya terdapat empat tujuan pengelolaan yang dikemukakan oleh YAUM Cirebon yaitu pertama, mengembangkan dan meningkatkan pelayanan infaq, shadawah, dan dana sosial lainnya bagi masyarakat sesuai dengan tuntunan agama. Kedua, meningkatkan kesadaran bagi para Agniya(orang yang mampu). Ketiga, Mewujudkan pemerataan dan pendayagunaan kepada mustahiq secara adil sesuai dengan ketentuan agama. Keempat, profesionalitas dalam pelaksanaan dana amanah dari ummat. Keempat tujuan tersebut dibalut dengan enam sasaran pendayagunaan antara lain pelayanan sosial(santunan sosial), pendidikan(beasiswa, beaguru), kesehatan(layanan kesehatan gratis), pendayaan ekonomi ummat, peningkatan kualitas SDM(berdayaguna) dan pengembangan lembaga da'wah.

\section{Program YAUM Cirebon: Bantu Sesama, Tebarkan Manfaat untuk Semua}

"Bantu Sesama, Tebarkan Manfaat untuk Semua" merupakan tag line yang diusung oleh lembaga ini. membantu sesama dalam hal ini adalah sesama ummat muslim secara khusus dan sesama manusia pada umumnya. Harapannya setelah memberikan bantuan tersebut dapat menyebarkan manfaat kepada semuanya.

Secara umum sejak tahun 2018-sekarang ada setidaknya lima program besar dengan 17 kegiatan dan lebih dari 2.213 penerima manfaaat. Program tersebut antara lain adalah program yang termasuk dalam 
kategori Donasi Sosial Kemanusiaan, Donasi Pendidikan, Donasi Dakwah Keummatan, Donasi untuk Kesehatan dan Donasi YAUM untuk Ummat.

Program donasi sosial kemanusiaan memiliki setidaknya tujuh deksripsi program atau kegiatan. Ketujuah kegiatan tersebut antara lain adalah santunan anak yatim dan dhuafa, santunan aromil atau janda dan jompo tidak mampu, jumat berkah yaitu pembagian nasi kotak gratis untuk dhuafa, santunan dhuafa, bantuan rutilahu atau rumah tangga tidak layak huni, bantuan bencana alam, dan santunan dana sosial umum. Secara spesifik nanti peneliti akan menjelaskan lebih mendalam terkait kegiatan junat berkah yang tetap dilakukan dimasa pandemi seperti ini.

Program donasi pendidikan memiliki empat kegiatan antara lain adalah Gerakan Orang Tua Asuh(GOTA), Roudhotul athfal Terbuka AlQudwah, bantuan biaya pendidikan, dan bimbingan belajar yatim dan dhuafa (YAUM Cerua). Setidaknya terdapat 46 penerima manfaat pada program ini. Selanjutnya adalah prgram dakwah keuamatan yang memiliki tiga kegiatan yaitu kafalah abdi masyarat, majelis taklim dan ruqyah masalh. Kurang lebih terdapat 155 penerima manfaat pada program ini.

Program donasi untuk kesehatan memiliki satu kegiatan yaitu pemerikasaan kesehatan dan pengobatan gratis dengan 100 penerima manfaat. selanjutnya adalah program donasi YAUM untuk ummat. Kegiatannya adalah semarah ramadhan YAUM dan qurban bersama YAUM. Pada program ini terdapat 625 penerima manfaat. Keseluruhan program dan kegiatan tersebut terangkum dalam tabel berikut:

Tabel 1. Program Yayasan Amnah Ummat Muslimin tahun 2018 - sekarang

\begin{tabular}{llc}
\hline PROGRAM & \multicolumn{1}{c}{ DESKRIPSI PROGRAM } & $\begin{array}{c}\text { PENERIMA } \\
\text { MANFAAT }\end{array}$ \\
\hline Donasi Sosial & 1. Santunan Anak Yatim dan Dhuafa & 193 Anak \\
Kemanusiaan & $\begin{array}{l}\text { 2. Santunan Aromil (Janda \& Jompo } \\
\text { tidak Mampu) }\end{array}$ & 28 Orang \\
& $\begin{array}{l}\text { 3. Jumat Berkah (Pembagian Nasio } \\
\text { Kota Gratis) }\end{array}$ & 1041 Orang \\
& $\begin{array}{l}\text { 4. Santunan Dhuafa } \\
\text { 20 Orang }\end{array}$
\end{tabular}


5. Bantuan Rulitah(Rumah Tidak Layak huni)

6. Bantuan Bencana Alam

7. Santunan Dana Sosial Umum

Donasi

Pendidikan

Donasi Dakwah

Keumatan

Donasi untuk

Kesehatan

Donasi YAUM

untuk Ummat
1. Gerakan Orang Tua Asuh (GOAT)

2. RA Terbuka Al-Qudwah

3. Bantuan Biaya Pendidikan (Beasiswa)

4. Bimbingan Belajar Yatim \& Dhuafa (YAUM Ceria)

1. Kafalah Abdi Masyarakat

2. Majelis Taklim

3. Ruqyah Masal

1. Periksa Kesehatan dan Pengobatan Gratis

1. Semarak Ramadhan YAUM

2. Idul Adha (Qurban bersama YAUM)
3 Orang

Global

2 Orang

3 Anak

1 Lembaga

2 Orang

40 Anak

2 Penerima

3 MT

150 Orang

100 Orang

525 Orang

100 Orang

Sumber: Data diolah dari Proposal ZISWAF Ramadhan YAUM Cirebon 2020

\section{Implementasi Filantropi melalui Program Jum'at Berkah}

Program Jum'at Berkah ini seperti gerakan sedekah yang dilakukan pada hari Jum'at, dalam penyaluran bantuan paket Jum'at Berkah biasanya berupa paket makan siang ataupun beras yang berisi 2,5 - $5 \mathrm{~kg}$ beras yang nanti akan disebarkan kepada masyarakat yang berada di titik wilayah yang sudah ditentukan oleh YAUM Cirebon..$^{24}$

Untuk lokasi yang menjadi titik penyebaran Jum'at Berkah diantaranya wilayah kota dan Kabupaten Cirebon sekitarnya. Setidaknya dalam penyaluran paket nasi jum'at berkah setiap pekannya ada 100-150

\footnotetext{
${ }^{24}$ Wawancara dengan Fatimah 30/12/2020 
paket nasi yang YAUM Cirebon salurkan. Target penerima manfaat paket Jum'at Berkah yakni masyarakat menengah kebawah, biasanya para tukang becak, pemulung, pedagang asongan, tukang sampah, supir angkot, dan masyarakat lainnya yang memang terlihat sangat memprihatinkan keadaanya. Menurut Silvia relawan YAUM Cirebon:

“Biasanya untuk menentukan titik lokasi untuk membagi-bagikan nasi itu sesuai permintaan donator, kalau donator membebaskan, nanti kita cari titik yang sesuai dengan targetnya. Untuk titik yang tidak ditentukan oleh pihak donator, biasanya diserahkan kepada relawan"25

Program Jum'at Berkah Cirebon dalam pelaksanaanya melakukan sinergi dengan beberapa komunitas atau mitra YAUM, salah satunya adalah Every Friday One Food (EFOF) Cirebon. EFOF Cirebon merupakan donator atau mitra tetap YAUM dalam mendukung program jum'at berkah seperti memberikan beras dan nasi untuk penerima manfaat kegiatan Jum'at Berkah. Menurut Ati Fatimah relawan tetap YAUM Cirebon,

"Sejak tahun 2018 sampai 2020 telah ada 2.800 penerima manfaat dari program Jum'at Berkah, biasanya EFOF memberikan kontribusi untuk pelaksanaan Jum'at Berkah berupa beras 2,5 kg".26

Kegiatan Jum'at Berkah ini adalah kegiatan rutinan yang dilakukan oleh setiap minggunya. Ini merupakan salah satu bentuk implementasi filantropi yang dilakukan lembaga sosial dalam pengabdian yang dilakukan kepada masyarakat menengah bawah atau yang membutuhkan. Dalam kegiatan Jum'at berkah juga tidak terlepas dari peran dan kontribusi para donator yang telah bersedia menyisihkan rezeki nya untuk pelaksanaan program-program YAUM Cirebon. ${ }^{27}$

Implementasi kegiatan Jum'at Berkah yakni dengan mebagibagikan sepaket makan siang untuk masyarakat menengah bawah atau kaum duafa. Kegiatan Jum'at Berkah ini adalah salah satu program bantuan sosial YAUM Cirebon. Kegiatan Jum'at Berkah dilaksanakan setiap hari Jum'at Pukul 13.00 atau setelah sholat Jum'at sampai dengan jam 15.00 sore. Kegiatan ini dilakukan oleh relawan YAUM, kegiatan penyaluran Jum'at

\footnotetext{
${ }^{25}$ Wawancara dengan Silvia, 4 /10/2020

26 Wawancara dengan Fatimah...

${ }^{27}$ Buku Profil YAUM Cirebon
} 
Berkah di satu titik wilayah yang sudah ditentukan dengan melibatkan RT/RW dan para relawan dalam pelaksanaanya dengan menyebarkan kupon paket jum'at berkah kepada warga yang ada di titik lokasi sesuai dengan rekomendasi RT/RW setempat. Pengambilan paket nasi jum'at berkah dilakukan setelah shalat jumat dengan melakukan penukaran kupon paket nasi. Penggunaan kupon jum'at berkah bertujuan untuk menghindari penerima manfaat mengambil paket nasi lebih dari satu, dan agar lebih tertib. Menurut Teh Ati Fatimah relawan YAUM Cirebon:

"Saat Pandemik seperti ini, penyaluran jum'at berkah dilakukan secara door to door atau langsung diberikan kepada penerima manfaat oleh relawan YAUM. Lokasi di tempat secara langsung tanpa adanya intruksi untuk berkumpul. Selain sistem penyaluran secara door to door, penyaluran jum'at berkah juga dilakukan secara drive true yakni para relawan yang menggunakan kendaraan bermotor langsung memberikan kepada orang yang terllihat dan menjadi target penerima" 28

Menurut Septyani, relawan YAUM Cirebon:

"Program Jum'at Berkah ini adalah salah satu upaya melatih diri kita dan manusia lain untuk saling berbagi meski hanya sedikit, dan kenapa di hari Jum'at karena, pahala berlipat ganda ketika hal kebaikan dilakukan di hari Jum'at. Itu bisa menarik para donator untuk ikut berkontribusi, Wallahu'ala bi showab"29

Mengingat bahwa saat ini Indonesia sedang menghadapi Pandemic COVID-19, untuk itu Kegiatan Jum'at Berkah ini salah satu bentuk kegiatan sosial yang dilakukan lembaga sosial dalam membantu masyarakat menengah bawah yang terkena dampak COVID-19. Dalam pelaksanaanya relawan juga tetap melakukan kegiatan dengan memperthatikan protocol kesehatan sesuai dengan arahan dari Pemerintah.

Adanya program Jum'at Berkah ini memberikan dampak yang baik bagi masyarakat atau penerima manfaat, Program Jum'at Berkah ini merupakan salah satu bentuk kepedulian YAUM dengan masyarakat

\footnotetext{
${ }^{28}$ Wawancara dengan Fatimah....

29 Wawancara dengan Cici Setiyani relawan YAUM Cirebon mengenai program Jum'at Berkah, wawancara di lakukan 2 Oktober 2020 pukul 11:55 WIB. 
sekitar. karenanya mereka merasa terbantu walau hanya dengan sekotak nasi yang diberikan. Menurut Teh Silvia relawan YAUM Cirebon:

"Karena, diluar sana masih banyak masyarakat yang belum bisa memenuhi kebutuhan pokonya, bahkan jikapun mereka bisa makan, belum tentu gizinya itu terpenuhi". ${ }^{30}$

Dilihat dari Implementasi Filantropi yang dilakukan YAUM Cirebon melalui program Jum'at Berkah ini memberikan dampak yang baik, karena lembaga sosial seperti YAUM selalu berperan aktif untuk ikut berkontribusi membantu masyarakat menengah bawah terutama pada masa pandemic seperti ini. Setidaknya sebagian orang telah tercukupi makan siangnya melalui jum'at berkah ini.

\section{YAUM Peduli Wabah Corona (COVID-19)}

Program YAUM Peduli wabah corona adalah program penggalangan dana bantuan kepada masyarakat sebagai bentuk respon cepat dari YAUM terhadap pandemi corona virus COVID-19. Program tersebut terbagi menjadi beberapa kegiatan yang sasarannnya adalah masyarakat kurang mampu ataupun tenaga kesehatan. Bantuan pertama adakag sembako dhuafa atau masyarakat terdampak corona COVID-19, bantuan APD, masker N95 \& Sepatu Boots untuk RSUD Gunung Jati, RSUD Waled Cirebon, dan RS Paru Sidawangi. Ada lagi bantuan APD, Masker \& Hand Sanitizer yang diberikan kepada Puskesmas Ciperna, Puskesmas Waled Puskesmas Majasem, Puskesmas Mundu \& Puskesmas Gegesik. Bantuan-bantuan tersebut merupakan penggalangan donasi yang dilakukan khusus dalam penanganan pandemi ini.

\section{SIMPULAN}

Dari pembahasan di atas, bahwasannya dapat disimpulkan: impelemntasi program filantropi yang dilakukan oleh YAUM Cirebon terbagi menjadi 5 program besar dengan 17 kegiatan dan 2213 penerima manfaat. salah satu kegiatan unggulan dari bantuan yang diberikan YAUM Cirebon jika dilihat dari penerima manfaatnya adalah Juat

\footnotetext{
30 Wawancara dengan Silvia relawan YAUM Cirebon, 4 Oktober 2020, pukul 14.38 WIB
} 
Berkah(Pembagian Nasi Kotak Gratis untuk Dhuafa). Dilihat dari Implementasi Filantropi yang dilakukan YAUM Cirebon melalui program Jum'at Berkah ini memberikan dampak positive bagi penerima manfaat atau masyarakat yang membutuhkan. Seperti saat ini masyarakat Indonesia sedang menghadapi COVID-19, untuk itu lembaga-lembaga sosial seperti YAUM Cirebon ini berperan aktif terlibat dalam bantuan sosial. Setidaknya sebagian orang telah tercukupi makan siangnya melalui jum'at berkah ini.

Secara khusus YAUM Cirebon melakukan impelemetasi program filantropi pada masa pandemi corona virus COVID-19 pada program bantuan kepada dhuafa dan tenaga medis. Bantuan diberikan berupa sembako dhuafa masyarakat terdampak covid, dan bantuan APD, masker, sepatu boots, dan hand sanitizer.

\section{DAFTAR PUSTAKA}

Admin. "Filantropi dalam Perspektif Islam." republika.co.id. Diakses 12 Desember 2020. https://republika.co.id/berita/p5qn6r396/filantopidalam-persfektif-islam.

Azizi, M. Zaky Wahyuddin. "Optimalisasi Peran Lembaga Filantropi Islam." Vol. $\quad 01 . \quad 2007$. http://publikasiilmiah.ums.ac.id/handle/11617/1061.

BASZNAS. Statistik Zakat Nasional 2017. Badan Amil Zakat Nasional. Jakarta: Bagian Liaison dan Pelaporan, 2018. file:///C:/Users/User/Downloads/fvm939e.pdf.

BAZNAS. Indonesia Zakat Outlook 2019. Jakarta: PUSKAS BAZNAS, 2019.

BNPB. “Status Keadaan Tertentu Darurat Bencana Wabah Penyakit Akibat Virus Corona di Indonesia." bnpb.go.id, 2020. https://bnpb.go.id/berita/status-keadaan-tertentu-darurat-bencanawabah-penyakit-akibat-virus-corona-di-indonesia-.

Chuswinta, Rochmatul, Tri Sudarwanto, dan M. Syam'un Rosyadi. "Implementasi Pengelolaan Dana Infaq Dalam Meningkatkan Kesejahteraan Masyarakat Jombang (Studi Kasus Lembaga Sosial Pesantren Tebuireng"LSPT")." JIES: Journal of Islamic Economics Studies.

Vol. 1, 4 November 2020. https://ejournal.feunhasy.ac.id/jies. Djatmiko, Harry. "Re-Formulation Zakat System as Tax Reduction in 
Indonesia." Indonesian Journal of Islam and Muslim Societies 9, no. 1 (24 Mei 2019): 135. https://doi.org/10.18326/ijims.v9i1.135-162.

Hasan, M. Iqbal. Pokok-pokok Metodologi Penelitian dan Apliaksinya. Bogor: Ghalia Indonesia, 2002.

Jaya, Pajar Hatma Indra. “'Mas Zakky': Model Zakat pemberdayaan dari Baznas Kota Yogyakarta." Jurnal Pemberdayaan Masyarakat: Media Pemikiran dan Dakwah Pembangunan 2, no. 2 (23 Juni 2019): 227-52. https://doi.org/10.14421/jpm.2018.022-02.

Jusuf, Chusnan. "Filantropi Modern untuk Pembangunan Sosial." Sosio $\begin{array}{llllll}\text { Konsepsia. } & \text { Vol. } & 12, & 1 & \text { Januari } & 2007 .\end{array}$ https://doi.org/10.33007/SKA.V12I1.621.

Linge, Abdiansyah. "Filantropi Islam Sebagai Instrumen Keadilan Ekonomi." JURNAL PERSPEKTIF EKONOMI DARUSSALAM 1, no. 2 (2 Maret 2017): 154-71. https://doi.org/10.24815/jped.v1i2.6551.

Madjakusumah, Deden Gandana, dan Udin Saripudin. "Pengelolaan Dana Lembaga Filantropi Islam Dalam Pengembangan Ekonomi Umat." SERAMBI: Jurnal Ekonomi Manajemen dan Bisnis Islam 2, no. 1 (30 April 2020): 41-50. https://doi.org/10.36407/serambi.v2i1.151.

Mulyadi, Deddy. Studi Kebijakan Publik dan Pelayanan Publik. Bandung: Alfabeta, 2015.

Payton, Robert L., dan Michael P. Moody. Understanding Philanthropy: Its Meaning and Mission. Indianapolis: Indiana University Press, 2008.

Saidurrahman. "The Politics of Zakat Management in Indonesia: The Tension between BAZ and LAZ." Journal of Indonesian Islam 7, no. 2 (1 Desember 2013): 366-82. https://doi.org/10.15642/JIIS.2013.7.2.366-382.

Sriharini, dan Moh Abu Suhud. "Warung Beres Sebagai Modal Sosial Meningkatkan Produktifitas Ekonomi Umat: Studi Pemberdayaan Komunitas oleh Lembaga Amil Zakat Dompet Dhuafa Jogja di Kabupaten Gunungkidul." Jurnal Pemberdayaan Masyarakat: Media Pemikiran dan Dakwah Pembangunan 1, no. 1 (10 Agustus 2017): 119. https://doi.org/10.14421/jpm.2017.011-06.

Sugita, Ades, Dan Sri, dan Intan Wulandari. “Analisis Peranan Pengelolaan Dana Ziswaf Dalam Pemberdayaan Ekonomi Umat Pada Lazisnu Kabupaten Cirebon." Jurnal Indonesia Sosial Sains. Vol. 1, 28 Juli 2020. 
https://doi.org/10.36418/JISS.V1I1.6.

Sugiyono. Metode Penelitian Kuantitatif Kualitatif dan RED. Bandung: Alfabeta, 2010.

Tamim, Imron Hadi. "Peran Filantropi dalam Pengentasan Kemiskinan di dalam Komunitas Lokal." The Sociology of Islam 1, no. 1 (2011). http://jurnalfisip.uinsby.ac.id/index.php/JSI/article/view/8.

\section{Wawancara}

Wawancara dengan Silvia, 4/10/2020 .

Wawancara dengan Fatimah, 30/09/2020.

Wawancara dengan Setiyani, 2/10/2020. 